\title{
College English Writing MOOC Design \& Practice Based on the Online Writing Platform
}

\author{
Chang Chengxia \\ School of Foreign Language Studies, Henan Polytechnic University, Jiaozuo, China
}

Email address:

hpuccx@163.com

To cite this article:

Chang Chengxia. College English Writing MOOC Design \& Practice Based on the Online Writing Platform. Science Journal of Education. Vol. 5, No. 4, 2017, pp. 150-152. doi: 10.11648/j.sjedu.20170504.14

Received: April 7, 2017; Accepted: April 26, 2017; Published: June 21, 2017

\begin{abstract}
In the big data Era, College English teaching reform is inseperable from the advance in modern information technology. The paper aims to explore the new college English writing teaching approach with the introduction to the author's own college English writing MOOC design and two-term writing practice based on www.pigai.org(one of the most popular online Automated Scoring platforms in China). Besides, the paper also aims to enrich college English MOOC types and promote the further development of MOOC and online writing platform in college English writing teaching.
\end{abstract}

Keywords: Pigai Network, College English Writing MOOC Design, Teaching Practice

\section{Introduction}

Under the background of economic globalization, the vigorous development of social economy has enabled universities to cultivate high-quality talents with good English writing ability. High- quality MOOC videos provide learners with plenty of opportunities for real language data and language practice. The author tries to combine MOOC writing teaching videos, the online writing\& automated scoring platform and the advantages of traditional classroom teaching in college English writing teaching reform in China. The college English writing MOOC teaching method based on Pigai network consists of three parts: online, offline and evaluated. The new approach is carried out in three environments: QQ group of micro-class self-study, online writing \& automatic grading platform and classroom.

\section{The Necessity for the Application of www.Pigai.org to College English Writing Teaching}

The interaction in the traditional teaching process means that the face-to-face communication between teachers and students, that is to say, people communicate directly with each other in real time, which is convenient, efficient, and less misleading. However, its shortcomings can not be ignored.
Face-to-face interaction can only occur when there is spare time available on both sides, and it is restricted by time and place. In the traditional teaching mode, the number and frequency of information exchange are greatly reduced. On the contrary, college English writing MOOC teaching is supposed to use different communication technology to create a multimedia learning environment. This new type of teaching model has many advantages. First of all, the interaction can occur at any time and anywhere, the real-time interaction on the Internet can be as easy as face-to-face interaction. Second, learners can interact with different people through different media. Finally, the learner can manage his own learning process and gain a stronger motivation.

Internet technology has been widely used in listening and speaking teaching, but in China's English writing teaching still has a long way to go. In the reform of college English writing teaching, if the Internet interactive technology can be fully utilized, the shortcomings and limitations of the traditional teaching model centered on teachers will be overcome to some extent. The integration of modern information technology into college English writing teaching will improve efficiency, create a better teaching environment, and modernize teaching content and media. 


\section{College English Writing MOOC Design \& Practice Based on www.pigai.org}

In order to promote the deep learning of English, that is, the occurrence of effective learning, to further improve the quality of college English writing teaching, the author tries to fit MOOC teaching method and online writing \& automated scoring platform into the traditional classroom writing teaching. The author's initiatives, after two semesters of experimental teaching practice and optimization, are welcome by the students and gained positive feedback. In the following part, the author introduces the MOOC teaching mode of college English writing based on Pigai network from three aspects: student group, teaching practice and teaching reflection.

\subsection{Student Group}

Students who are enrolled in the MOOC teaching model are sophomores in Henan Polytechnic University. They are non-English majors, about 300 students and 11 teaching classes.

\subsection{Teaching Practice}

\subsubsection{Pre-writing Phase}

At this stage, the teacher prepares the MOOC videos and some translation exercises according to the writing theme and assigns to students through the QQ group. Then Students have an easy access to the vocabulary and sentence structure related to the writing subject. Besides, the teacher will notify students of the writing task on Pigai Network and the deadline for them to submit.

After MOOC video learning and translation exercises, all students are asked to search for more material related to writing topics on the Internet, helping them to broaden their horizons and inspire ideas. Eventually they set up their own writing ideas, the structure and content of the article. Students have the autonomy to choose any information or resources they are interested in, rather than passively receiving teacher's classroom instructional information. In this way, students have a lot of motivation to explore, take full advantage of their potential to analyze and solve the problem. A wealth of subject-related information, useful vocabulary and sentence structures collected by other students can also be shared among all the students.

\subsubsection{Drafting and Self-Revision Stage}

Drafting is an important stage in the writing process. At this stage, the students should form a coherent text through communicating with their classmates or teachers during the process. After completing his or her first manuscript, the student will need to submit it to Pigai network, and the student's ariticle will be scored and commented immediately on line. The student will modify the manuscript repeatedly according to the suggestions provided by the online grading platform-the Pigai network.

\subsubsection{Peer Review and Revision Phase}

The teacher tracks and supervises students' writing on line, then makes use of "peer review" function on the Pigai network, randomly designating students to comment on each other's composition. The feedback will be available for students to modify their own writing.

Modification is another important stage in the writing process. This is a process of rethinking, rediscovering and reproducing content, and re-forming a new manuscript through it. Peer review can help students identify vocabulary and grammatical mistakes. Teachers can also provide suggestions on word selection, sentence structure, and even specific aspects such as spelling, grammar and punctuation. In the phase of peer review, the essays are randomly exchanged, and the evaluation is done by other students. Every student is fully involved in the modification process, so everyone will act actively.

\subsubsection{Teacher's Feedback \& Evaluation Stage}

After collecting all the suggestions for modification and peer feedback on Pigai network, the students modify and retouch their work, the final drafts are supposed to write down on the exercise-books and graded by the teacher manually. In the classroom teaching process, the teacher will give written feedback about the common problems and highlights in students' writing, and exchange and summarize the writing experience with students.

In addition, the teacher will make recommendation for the excellent essays through Pigai network and QQ group to all students so that they can take advantage of the excellent essays and improve their own writing competence.

\subsection{Teaching Reflection}

After two semesters' college English writing MOOC teaching practice based on Pigai Network, both teaching and learning have undergone great changes through the author's observation. The following section is an introduction to the influence of the new approach to the teaching of college English writing from the perspective of teachers' teaching and students' learning.

\subsubsection{Changes in Students' Learning}

For students, the stages of pre-writing, online self-revision and peer review, and teacher's feedback have undergone some evident changes.

First of all, learning in pre-writing stage has undergone obvious changes, such as the learning resources, learning methods and learning process. Pre-class resource learning includes teacher's MOOC videos and translation exercises through the QQ group, writing and reading resources collected on the Internet by all students. The web-based open learning environment is creative because all participants can exchange and share resources and discuss them. Through the online platform, students can get more ideas, and richer resources and inspiration, which in turn helps them to conceive, organize their own writing.

Second, the writing stage has also changed. The online 
network greatly facilitates this stage of learning and teaching activities. Through the Internet, collaborative learning activities can be done at any time and in any way. For example, in practice, the teacher can arrange students to perform peer review on line, exchange drafts and give feedback. Through the activities, teachers can provide the necessary guidance, meanwhile, students can also seek the teacher's personal opinions and suggestions.

Finally, the post-writing stage of learning has also undergone some changes. In the traditional classroom writing teaching mode, for most students, the writing study may be suspended with the teacher's manual grading. What's worse, teachers may not give timely written feedback because the class is too large. In the new teaching mode, through MOOC videos and Pigai Network, the classroom writing teaching effectively extends to students' after-class self-learning. The students' learning style becomes more interactive and autonomous, which enhances their sense of accomplishment and satisfaction. Hopefully, the new teaching mode enables students to actively carry out English writing and stimulates them to improve their English writing level.

\subsubsection{Changes in Teachers' Teaching}

In the traditional classroom writing teaching, teachers are the main body, because the classroom time is limited, the teachers' teaching is difficult to fully take into account the input and output. In the MOOC environment, according to the writing task, the teacher releases MOOC writing videos to students in advance, therefore, students can watch the teaching videos autonomously to achieve a true sense of personalized learning.

The new MOOC teaching method has led to changes in the role and function of teachers. Teachers should not only organize classroom teaching, but also perform multiple roles such as integrators, designers, learners and evaluators of MOOC writing video resources.

In coping with the online writing evaluation system, teachers are supposed to have the information technology literacy and knowledge literacy needed for the big data age. Besides, teachers should not use the system feedback data mechanically, but should be able to utilize the online data scientifically.

\section{Conclusion}

In the era of big data, MOOC and Pigai network provide important auxiliary system and tools for college English writing teaching. It is an effective way to promote the innovation of college English writing teaching and improve teaching quality. In the network environment, college English teachers need to update their educational concepts and improve their own information technology literacy, and conduct more theory and practice researches. Teachers should devote themselves to applying MOOC and the online automatic scoring platform to college English writing class, which is expected to improve teaching quality of College English writing and enhance students' writing competence.

\section{Acknowledgements}

This research was supported by Higher Education Teaching Reform Research and Practice Project in the Educational Department of Henan Province; The 12th Five-years Plan of Henan Science of Education (2015-JKGHYB-0064); The Humanities and Social Sciences Foundation Project in Henan Polytechnic University (72605/002/091).

\section{References}

[1] CHEN Qing-bin. (2016). Reconstruction of the Teaching Model of College English Writing in the Big Data Era. Foreign Language Research, 190(3):129-132.

[2] Da Liu. (2016). The Reform and Innovation of English Course: A Coherent Whole of MOOC, Flipped Classroom and ESP. Procidia-Social and Behavioral Science, 232(4): 280-286.

[3] DU Tie-juan. (2016). Research on the Innvation of College English Teaching Mode Based on MOOC. Journal of Beijing Institute of Education, 30(4):62-65.

[4] HU Shu-qin. (2015). The Network-Assited Process Approach in College English Writing Instruction inChina. Cross-Cultural Communication, 11(6):122-126.

[5] LI Fengiie, REN Jia \& ZHAO Hongyi. (2016). Grammatical Mistakes in College Engish Writing: Problem Analysis, Reasons and Solutions. International Journal of Applied Linguistics and Translation, 2(3):20-28.

[6] WANG Bing. (2017). The College English Teaching Reform Based on MOOC. English Language Teaching, 10(2):19-22.

[7] YANG Xiao-qiong \& DAI Yun-cai. (2015). An Empirical Study on College English Autonomous Wrting Teaching Model Based on www.pigai,org. Technology Enhanced Foreign Language Education,162(2):17-23.

[8] ZHANG Xin-ying \& LIN Yue. (2016). “College English Reading" MOOC Design. Industry and Information Technology Education, (8):53-58.

[9] ZHAO Xiao-wen \& SUI Xiao-bing. (2016). Reasearch on Practical Ways to Implement MOOC in College English Teaching. Journal of Social Science of Jamusi University, 34(5): 196-198.

[10] ZHOU Li. (2015). The Effect of Online Writing Platforms on College Studnets' Synthectic Ability. Technology Enhanced Foreign Language Education, 165(9):26-29.

[11] ZHONG Cai-shun. (2015). Study on Autonomous Writing Revision Based on Online Antomated Feedback. Journal of PLA University of Foreign Languages, 38(4): 81-88. 